\title{
Ancient Procedures for the High-Tech World: Health Benefits and Antimicrobial Compounds from the Mediterranean Empires
}

\author{
Carla C.C.R. de Carvalho ${ }^{1, *}$ and Maria José Caramujo ${ }^{2}$
}

${ }^{I} I B B-I n s t i t u t e$ for Biotechnology and Bioengineering, Centre for Biological and Chemical Engineering, Instituto Superior Técnico, Av. Rovisco Pais, 1049-001 Lisboa, Portugal and ${ }^{2}$ Centre of Environmental Biology, Faculdade de Ciências, Universidade de Lisboa, Campo Grande C2, 1749-016 Lisboa, Portugal

\begin{abstract}
This paper reviews the benefits of the Mediterranean diet and methods developed for food processing and preservation during the time of the ancient empires. In Antiquity, trees and herbs were harvested for culinary and medicinal purposes, and from the everyday handling of products and keen observation, a great body of wisdom was derived by philosophers and physicians. With modern day techniques, the suspected properties of compounds have been investigated and the beneficial properties tested. From these studies it is apparent that olive oil, herbs, essential oils and metals, when used with the backing of scientific knowledge can improve human health and the standards of living while respecting the environment. Nowadays, proliferation of disinfectants and antimicrobial agents in domestic, industrial and medical environments has contributed to the appearance of resistant microbial strains and of new pathogens. Since regulators have restricted the use and concentrations of many preservatives, sanitizers, and antimicrobial agents, the food industry is facing a problem to extend the shelf-life of products, and to keep the manufacturing environment clean. The application of natural compounds and simple techniques developed by ancient Mediterranean civilizations may prove as useful as more modern synthetic substances, thus avoiding potential threats to human health and the environment.
\end{abstract}

\section{INTRODUCTION}

Human civilization has flourished in a panoply of environments as the result of the judicious use of chemicals and engineering techniques. Ancient civilizations relied on nature as a source of products and procedures in the battle against bacteria, virus, and parasites. In the XX century, natural products such as penicillin were found to possess remarkable antimicrobial activity and therapeutic properties [1]. However, the first penicillins discovered had a narrow spectrum of activity and low chemical stability and were destroyed by some bacterial strains able to produce the enzyme penicillinase [2]. In the last half of the XX century, synthetically modified penicillins, semi-synthetic pharmaceuticals using natural compounds as building blocks, as well as many other totally synthetic drugs have been also designed and produced. The use of modern chemicals is widespread, yet natural and ancient products (or chemicals extracted from these products) have claimed a renewed attention in the last decades. The increased interest in natural products derives, in part, from both the real and imagined effects of synthetic additives and preservatives upon human health and, in part, from the ethical awareness of consumers towards the release of these and other synthetic chemicals into the environment.

In Antiquity, trees and herbs were harvested for culinary and medicinal purposes, and gardens with these useful species were planted. Egyptians, Greeks and Romans, all had

\footnotetext{
*Address correspondence to this author at the IBB-Institute for Biotechnology and Bioengineering, Centre for Biological and Chemical Engineering, Instituto Superior Técnico, Av. Rovisco Pais, 1049-001 Lisboa, Portugal; Tel: +351-21-8419594; Fax: +351-21-8419062;

E-mail: ccarvalho@ist.utl.pt
}

their gardens and profited from the knowledge acquired when conquering the empires of one another. Amongst the Greeks, several authors mentioned fragrant gardens and their plants and uses: Herodotus (ca. 440 B.C.) in his "Histories" $[3,4]$, Hippocrates (ca. 460-370 B.C.) in the medical writings compiled under the name of Corpus Hippocraticum, and Theophrastus (ca. 370-288/5 B.C.) in his botanical work "Enquiry into Plants" [5-7].

The interest in the properties of plants and herbs was also documented during the Roman times by Pliny, the Elder (23/24-79 A.D.) in his encyclopaedic "The Natural History" [8], and by the Greek physician Discorides (40 - 90 A.D.) whose Herbal or De Materia Medica detailed the medicinal use of an enormous number of plants [9]. This major source of herbal knowledge was the precursor to all modern pharmacopeias and remained in use until the XVI century [10]. Galen of Pergamon (131-201 A.D.) incorporated some of Discorides' knowledge when writing his medical works [11]. However, after the fall of Rome, much of this herbal wisdom was retained only in the eastern parts of the former Roman Empire. In the late 10th and early 11th centuries, the Persian physician and Islamic scholar Alī ibn Sīnā (known in the West as Avicenna) wrote a series of volumes known as 'The Canon of Medicine' that were a compilation of the total medical knowledge available at the time [12]. This medical encyclopaedia, which included the Hippocratic and Galenic traditions, Syro-Arab and Indo-Persian practice, plus notes based on Ibn Sina's own observations, became the definitive medical canon and was included in the curriculum of European medical schools until the 17 th century. In this canon were also described methods of distillation and the effects on 
the human body of more than 800 plants, thus continuing the tradition of Hippocrates who recommended the use of herbs, olive oil and aromatic oils as conducive to good health.

Never before in human history has the food been so well preserved as in the last century. The access to refrigerating systems at home, the addition of preservatives to food, the use of sterile procedures and packages, and the understanding of food contamination during food processing, have all contributed to the access of even exotic food and beverages and their storage. However, these new techniques and additives are adding a selective pressure on micro-organisms, leading to an emergence of stronger pathogens. An example of this is Saccharomyces cerevisiae Meyen ex E.C. Hansen 1883 [13] which has been used for centuries to make bread, beer and wine. Always considered as a non-pathogen, it has in the last decades been implicated in human infections e.g. pneumonia, endocarditis, peritonitis and vaginitis [14, 15]. Most of these infections are opportunistic, occurring in immunocompromised patients but not all, accounting already for $c a .5 \%$ of all vaginal infections [16]. The subtype of $S$. cerevisiae known as S. cerevisiae Hansen CBS 5926 (formely known as $S$. boulardii; molecular typing is required to distinguish this subtype from $S$. cerevisiae strains) has been used in Europe as a probiotic agent for the re-equilibration of the intestinal tract. Septicemia and fungemia have recently been described in both immunocompromised and immunocompetent patients using this biotherapy, suggesting that this yeast can transit from the intestinal tract to the bloodstream $[17,18]$.

Listerioses caused by Listeria monocytogenes are usually sporadic, but several outbreaks have been reported, mainly via food-borne transmission [19, 20]. The first tetracycline resistant strains of L. monocytogenes were isolated in 1988 [21], as well as the first multi-resistant strain [22]. Transference by conjugation of enterococcal and streptococcal plasmids and transposons, conferring antibiotic resistance, from Enterococcus and Streptococcus to Listeria has been described (for a review on antibiotic resistance in Listeria spp. see [23]). Microbial resistance to antimicrobial agents has become an important problem, especially in healthcare units. Examples of an observed increased resistance in bacteria include the pathogens meticillin-resistant Staphylococcus aureus (MRSA), ciprofloxacin-resistant Pseudomonas aeruginosa, ciprofloxacin- or ofloxacin-resistant Escherichia coli, and multidrug-resistant strains of Mycobacterium tuberculosis. MRSA infections outside healthcare units were extremely rare, but increasing number of cases of communityacquired MRSA have been observed [24]. However, many of the most important pharmaceutical companies have stopped the development of new anti-infective agents [25], mainly due to the relatively low return of investment [26].

Other pathogens are becoming more resistant and infectious as noted by Skovgaard in his review of the impact of new food technologies on the emergence of pathogens [27]. Additionally, carcinogenic effects of synthetic antioxidants (e.g. BHT, butylated hydroxytoluene, and BHA, butylated hydroxyanisole) used in industrial food processing have been observed in animals [28]. BHA has caused tumours in the forestomach of rats, mice and hamsters and tumours in fish [29, 30]. However, the US Food and Drug Administration (FDA) currently permits the use of BHA and BHT as food additives after toxicity evaluations by FASEB [31] failed to establish that such problems could exist in humans, which do not possess forestomachs.

Phenolic and terpene compounds present in essential oils of e.g. oregano, thyme, sage, rosemary, coriander and garlic are known to possess antimicrobial activity. Most of these compounds may be classified as "Generally Recognised As Safe" (GRAS) and can be added to foods to seafood to the demands of increasingly health- and nutrition conscious consumers. Herbs, fruits, seeds and their oils are beginning to be considered as a valid alternative to artificial drugs used in medicine and as natural preservatives of food. Here we present an account of the present knowledge regarding these natural products and the active substance contained in them. We focused on their application in medicine and as antimicrobial agents in food.

\section{HEALTH BENEFITS DERIVING FROM THE MEDI- TERRANEAN DIET}

\section{Olive Oil}

The origin of the olive tree Olea europaea subsp. europaea L. (Family Oleaceae) is not known and its history is mingled with that of the ancient Mediterranean. It is assumed that people started to collect and squeeze olives in stone mortars since ca. $5000 \mathrm{BC}$ [32] and charred olive remains or olive pressing devices, indicative of olive oil production and dating from the fourth century B.C. have been found throughout the Mediterranean region [33, 34]. Biblical references to olive oil identify it as a constant presence in daily dishes (Leviticus 2, 4-5, 14-15). The existence of olive oil amphorae stored in the Minoan palaces, and of Syrian documents indicating that by 2000 B.C. olive oil was worth five times more than wine and two and a half time more than seed oils, suggest that olive oil was a valuable and nutritious food and trade commodity in those days $[35,36]$. In antiquity, it was recognised that the place of origin of olives was a good indicator of oil quality and was thus mentioned when evaluating or trading olive oil [8]; a possible precursor to the European "Protected Designation of Origin" for wine and food [37]. The importance of olive oil for the Romans is highlighted by its presence in the rations of soldiers during war campaigns (44-70 mL per soldier per day) and the fact that when reduced to eating butter, Romans considered it a hardship [38]. The medical properties of olive oil were recognised from Hippocrates to Galen $[5,11]$ and Hippocrates referred to olive oil as "the great therapeutic", purportedly beneficial for more than 60 therapeutic uses [39]. However, the mode of action of olive oil or the active components of olive oil ascribing it therapeutic properties were only clarified in the 20th century. Epidemiological as well as biochemical studies have confirmed the beneficial health effects of olive oil, and the benefits of a Mediterranean diet are recognised [40].

The role of dietary fats and their involvement in heart diseases elicited great interest in the scientific community during the last few decades. It is now apparent that the therapeutic value of olive oil derives from its unique composition in mono-unsaturated fatty acids (mainly oleic acid, C18:1 199$)$ as well as non-vitamin antioxidants such as phenolic compounds (Fig. 1), squalene, and vitamins. Oleic acid is believed to retard the progression of atherosclerosis when it is 
<smiles>C/C=C1/C(OC2OC(CO)C(O)C(O)C2O)OC=C(C(C)=O)C1CC(=O)OCCc1ccc(O)c(O)c1</smiles>

oleuropein<smiles>OCCc1ccc(O)c(O)c1</smiles>

hydroxytyrosol<smiles>OCCc1ccc(O)cc1</smiles>

tyrosol

Fig. (1). The three most common phenolic compounds in olive drupe, leaves and oil.

included in low density lipoproteins (LDL) because these lipoproteins become resistant to oxidation [41]. However, the non-lipid components of olive oil are potent free radical scavengers, inhibit chemically induced LDL oxidation, potentiate the macrophage response to endotoxin challenge by increasing their production of NO, inhibit the enzyme xanthine oxidase, potentiate the activity of $\alpha$-tocopherol (vitamin E), and protect cells against cancer ([42-44]; see also Table 1). The indirect effect of phenols also include: inhibition of phospholipase A2, thus preventing the release of arachidonic acid from membrane phospholipids, reducing the production of chemotactic and inflammatory compounds [45]; inhibition of lipoxygenase and cyclo-oxygenase [46]; inhibition of platelet aggregation and eicosanoid producion by activated leukocytes, thus having an antiatherogenic effect [47, 48]; and reduction of the bioavailability of food carcinogens and inhibition of their metabolic activation [49].

Extra-virgin olive oil (EVO) obtained by cold-pressing of olives has abundant non-lipid compounds (e.g. polyphenols, and principally hydroxytyrosol) as opposed to the refined oil that retains only a low amount of these compounds. The importance of anti-oxidants present in EVO has been shown in epidemiological studies regarding the protection of LDL in the blood stream against oxidation, in men with peripheral vascular disease (Fontaine stage II) [50]; and in studies showing that the scavenging of the hydroxyl radical in the plasma was significantly higher among extracts of olive oil relative to other seed oils of equivalent fatty acid composition [51].

The presence of antioxidants in the diet may reduce oxidative stress through inhibition of lipid peroxidation, a factor that is currently linked to a host of diseases such as cancer and heart disease (Table 1). Polyphenols present in extravirgin olive oil possess an array of potentially beneficial lipoxygenase-inhibitory, prostaglandin-sparing, and antioxidant properties [52]. This suggests that they may be able to reduce 5-lipoxygenase-driven cellular recruitment of leukocytes and the damaging consequences of their ability to release reactive oxygen species (ROS) whilst leaving unimpaired the generation of prostaglandins, which promote microvascular blood flow and act as immunomodulators. The enzymatic system xanthine oxidase and its substrate, xanthine, is likely to play a key role in the small intestine physiopathology. Reactive oxygen metabolites have been impli- cated as mediators of the tissue injury observed in several diseases of the gastrointestinal tract, and their formation from xanthine oxidase is considered a primary mechanism of cellular damage. It was shown that certain types of polyphenols have the ability to protect human intestinal Caco- 2 cells from $\mathrm{H}_{2} \mathrm{O}_{2}$-induced oxidative injury ([53], see also references therein). In this study, the phenol (3,4-dihydroxyphenyl) ethanol offered complete antioxidant protection from a concentration of $100 \mu \mathrm{mol} / \mathrm{L}$ when oxidative stress was induced by xanthine oxidase while (p-hydroxyphenyl)ethanol was ineffective up to a concentration of $500 \mu \mathrm{mol} / \mathrm{L}$. The study demonstrated that the ortho-dihydroxy moiety of the molecule was essential in this type of antioxidant activity, and confirmed previous observations on the relationship between the chemical structure and the antioxidant activity of polyphenols [54]. The high content of squalene in olive oil was also proposed as a major factor ascribing olive oil its inhibitory action in carcinogenesis [55]. Squalene is a hydrocarbon of the triterpene type, and is a key intermediate in the biosynthetic pathway of steroids in both plants and animals. Squalene has a strong inhibitory activity of HMG-CoA redutase, which reduces the availability of farnesyl pyrophosphate for farnesylation (phenylation) of the ras oncogene, yet, to our knowledge, it is not fully established how squalene inhibits the activity of this enzyme. Squalene also seems to lack the ability to decrease NO synthesis induced by phorbol 12-myristate 13-acetate (PMA) in macrophage cultures, and the ability to inhibit the formation of $\mathrm{O}_{2}$ or $\mathrm{H}_{2} \mathrm{O}_{2}$ [44].

Oxidant metabolites are continuously formed in living systems, and endogenous defense mechanisms are in place to counteract the effect of these oxidant molecules. However, the endogenous defense mechanisms seem to be insufficient for the complete prevention of oxidative damage, and different sources of dietary antioxidants may be required. Phenolics from olive oil (as well as from other foodstuffs present within the Mediterranean diet) may in this way help to protect against those factors causing degenerative disorders.

\section{Spices and Herbs}

\section{Rosemary}

Spices and herbs were common in ancient Egypt, China and India where they were used widely. Rosemary, Rosmarinus officinalis L. (Family Lamiaceae) is, among the herbs and 
shrubs with known antioxidant properties, the most widely used for millennia throughout the Mediterranean area. In antiquity, it was employed in multiple uses including medicinal uses (Pliny HN 29.99-100 [8]; Discorides 3.89 [9]).

Rosemary is used both for direct human consumption as an herb and, because of its potent antioxidant properties, it is used by the food industry as a safe and broad spectrum preservative for numerous types of processed and raw foods. The latter application derives from its ability to safely kill a wide range of micro-organisms ([56]; see Table 3), at concentrations that do not produce human or animal toxicity. Because of its strong antioxidant properties, rosemary extracts have preservative powers comparable to the commercial preservatives butylated hydroxytoluene (BHT) and butylated hydroxyanisol (BHA) [57, 58]. The principal antioxidant active compounds of rosemary are phenols and terpenes like carnosic acid, carnosol, rosmanol, and rosmarinic acid, although the relative amount may vary with location and harvest season $[59,60]$. Various studies of extracts of rosemary leaves have demonstrated that the biologically active constituents act as free radical scavengers, and are involved in the regulation of the activity of certain enzymes ([61-64], see Table 1). Pérez-Fons et al. proposed other forms of antioxidant activity for diterpenes which prevent the penetration and propagation of free radicals into biological membranes through its capability to increase lipid order (i.e. by having rigidifying effects) [65]. Rosemary extracts are also effective inhibitors of xanthine oxidase which is one of the most important enzymes producing $\mathrm{O}_{2}$ in living biological systems [66]. Additionally, carnosol and carnosonic acid has been reported to possess anticarcinogenic properties [67]. Carnosol ability to inhibit the protein kinase $\mathrm{C}$ activation may be related to its ability to promote isotropic structures in the phospholipid layer of biological membranes where protein kinase $\mathrm{C}$ association and activation occurs, resulting in cancer chemopreventive activity [65]. The anticarcinogenic activity of carnosic acid is probably related to its ability to further decrease the membrane fluidity of tumour cells, which contain less cholesterol and more unsaturated phospholipids than normal cells [68].

\section{Myrrh and Frankincense}

Myrrh and frankincense are aromatic gum-resins of several shrubs of the Family Burseraceae, belonging to the ge- nus Commiphora and certain trees of the genus Boswellia, respectively [69-71]. Both resins were used in antiquity for religious and medicinal purposes. Myrrh was the main ingredient for ancient Egyptian Kyphi incense, and in the 5th century BC, Herodotus noted that myrrh was used by the Egyptians for their embalming [3]. Moses was instructed by God to use myrrh as one of the main ingredients in a holy oil for anointing the priests (Exodus 30:22-33).

Although the chemical composition of myrrh is known in detail [69], clinical studies regarding the use of myrrh are scarce despite its numerous traditional medical uses throughout Africa, China and the Middle East ([72], see Table 1). The majority of the published research studies on the plant and its extracts have originated from India. Several pharmacologically active components have been identified in the plant, including guggulsterones (E- and Z-stereoisomers) and gugulipid [73-75]. Guggulsterones are reputed to lower blood lipids, including cholesterol. Studies have shown that guggulsterones act as antagonist ligands of the farnesoid X receptor (FXR). FXR is a nuclear hormone receptor that is activated by bile salts and induces bile salt export pump (BSEP) but inhibits cholesterol 7 $\alpha$-hydrolase (CYP7A1) gene transcription in the liver [76, 77]. Guggulsterones antagonize FXR activated genes thus inhibiting bile acid secretion from hepatocytes and bile acid sythesis. As a result, there is an increase of hepatic cholesterol and a decrease of intestinal cholesterol which lowers cholesterol in the plasma $[76,77]$. Whole myrrh extracts are also reported to have the ability to reduce lipid peroxidation in liver homogenates of mice and reduce lead genotoxicity in bone marrow chromosomes of mice [78]. Additionally, triterpenes identified as myrrhanol $\mathrm{A}$ and myrrhanone $\mathrm{A}$ isolated from myrrh have been noted for their anti-inflammatory capability [79].

Frankincense is a rich source of terpenes and boswellic acids [71, 80, 81]. Several studies reported the antioxidant properties of essential oils, and anti-inflammatory and anticancer activity of essential oils or individual components obtained from the resin (see [70] for an updated list of references). Boswellic acids inhibit the 5-LOX (lipoxygenase) system, which is involved in the enzymatic pathways which produce inflammatory molecules (leukotrienes and thromboxanes) from common fatty acids and potentially have anticancer activities [71]. Drug products that inhibit these en-

Table 1. Medical Protective Properties of Total Extracts or Compounds Present in Olive Oil, Rosemary, Myrrh and Frankincense

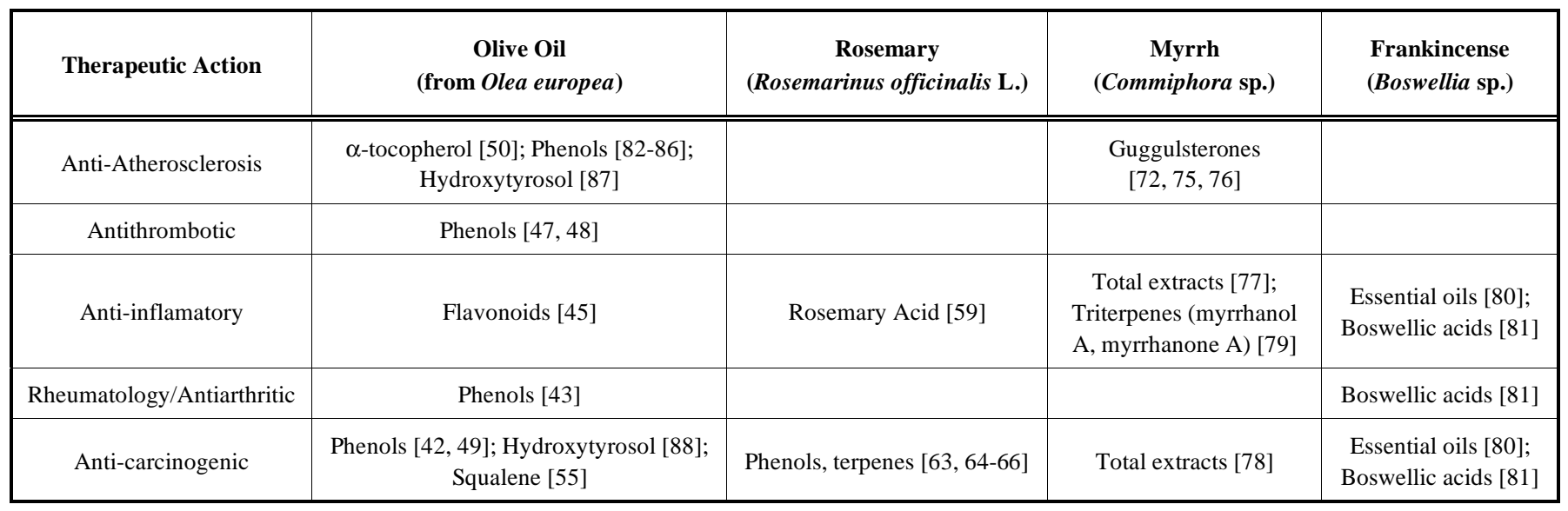


zymes are mainly used in the treatment of inflammatory disorders, in particular arthritis.,

\section{ANTIMICROBIAL AGENTS}

\section{Olive Oil}

In the 16th century $\mathrm{BC}$, the Phoenicians started disseminating the culture of olive trees throughout the Mediterranean, and later, the Roman Empire was responsible for expanding olive groves and oil mills in the Mediterranean basin [89]. Several techniques were used in the Roman period to preserve olives: half-ripe olives were harvested with stems, salted for five days and placed in jars filled with oil; green olives were kept in strong brine or with spices and vinegar; half-ripe or ripe olives were smashed, seasoned with vinegar and spices such as coriander seeds, cumin, fennel and mint and placed in jars covered with oil [90]. In Mediterranean countries some of these recipes are still used, and cheese, pepper and fish are equally preserved by immersion in olive oil as in Roman times. The role of vinegar in the recipes was not fully understood in Roman times, but it is now known that slight acidification of the oil is enough to prevent botulism which can occur when an anaerobic environment allows the growth of Clostridium botulinum [91]. Nowadays, acidity and sterilisation are the two most used methods to control the growth of pathogenic spore-forming micro-organisms, such as $C$. botulinum.

Olive oil is mainly composed by the monounsaturated oleic acid (approximately 72\% [55]) and linoleic acid (ca. $21 \%$ [92]). Dilika and co-workers have observed antibacterial activity of oleic and linoleic acids, isolated from Helichrysum pedunculatum, against Gram-positive strains, such as Bacillus cereus, B. subtilis and Staphylococcus aureus but were inactive against Gram-negative bacteria [93]. MIC varied between 0.01 and $1.0 \mathrm{mg} / \mathrm{mL}$. The lack of an outer membrane in Gram-positive bacteria and a relatively high exclusion limit of the cell wall $(30000 \mathrm{D}$ in the vegetative cells of Bacillus megaterium) are responsible for their higher susceptibility to preservatives when compared to Gram-negative bacteria (for a review on the mode of action of preservative agents and microbial resistance mechanisms see [94]).

Together with fatty acids, olive oil contains $\mathrm{ca}$. $0.7 \%$ squalene [55], sterols (e.g. $\beta$-sitosterol, $\Delta 5$-avenasterol and campesterol [95]) and phenolic compounds. The latter can be divided into simple phenols, secoiridoids and lignans and all contribute to the unique flavour of virgin olive and prevent oxidative rancidity. The discrepancies in the total phenol content reported, which varied between 100 and $800 \mathrm{mg} / \mathrm{kg}$ in extra-virgin olive oil and 62 in refined oil, can be the result of inaccuracies in the analytical methods [96]. Nevertheless, type and total content of phenolic compounds is affected by cultivar, local environmental conditions and the degree of ripeness [97].

In olives, the most common phenolic compounds include the glycoside oleuropein, hydroxytyrosol and tyrosol, which are related structurally (Fig. 1). Oleuropein is the major phenolic compound (up to $14 \%$ in dried fruit) in olives but when the flesh of the unripe fruit is crushed (malaxation) [98] or as the fruit ripens [99] its abundance decreases and the concentration of the hydrolysis product of oleuropein, i.e. hydroxytyrosol, increases and becomes the most abundant phe- nol in olive oil [100]. In virgin olive oil, the main phenolic compounds are aglycones of oleuropein and ligstroside, followed by hydroxytyrosol, tyrosol, hydroxytyrosol acetate and lignans [101]. During the process to obtain oil from olives, hydrolytic enzymes (glycosidades and esterases) are released from the pulp and can modify oleuropein, glucosidic and ester bonds [102]. Since many of the phenolic and terpenic compounds present in olive oil, have a glycosidic and an ester function they will also be affected by these enzymes during pressing of the olives. As a result, the glycosidic parts will partition to the aqueous phase, while the phenolic and terpenic partition between the aqueous and organic phase according to their polarity and hydrophobicity, thus influencing the properties of the olive oil.

The resulting mill waste waters, known as "Amurca" by the Romans, were used at the time as a fertilizer, as herbicide and a pesticide [103]. It was also applied in furniture, belts and shoes to protect and hydrate; in food preservation to seal jars containing fruits; it was also used as a combustible and to feed livestock [104]. Amurca was even employed to produce hardened plaster with insect repellent properties. Olive mill waste water is nowadays a serious environmental problem in the Mediterranean area due to its high content on microbial growth-inhibiting constituents, in particular phenolic compounds. Several studies to solve the waste water problem are underway, including the production of high-valued compounds from the waste water using lipolytic yeasts [105].

The majority of the published studies have described antimicrobial activity of polyphenols in olives, olive mill wastewaters and olive leaves while only simple phenols have been tested in olive oil [106]. An olive extract, rich in biophenols, showed a higher and dose-dependent antimicrobial activity against Escherichia coli, Salmonella poona, Bacillus cereus, Saccharomyces cerevisiae and Candida albicans than the isolated quercetin, hydroxytyrosol and oleuropein [107]. The authors ascribed the results to the possible presence of other compounds in the extract. The extract was also more effective against Gram-positive bacteria.

The phenolic compounds of virgin olive oil presented a strong bactericidal effect against eight strains of Helicobacter pylori, which is responsible for ulcers and some types of gastric cancer; among the strains tested three were resistant to antibiotics [108]. The secoiridoid aglycones, in particular decarboxymethyl ligstroside aglycone, were the most effective phenolic components against $H$. pylori. In vitro, the compounds inhibited bacterial growth at concentrations as low as $1.3 \mu \mathrm{g} / \mathrm{mL}$ (much lower than the concentrations necessary with phenolic compounds from tea, wine and plant extracts) and were stable for hours in the acidic environment. Nevertheless, in vivo confirmation of their bioactivity is still required.

Table 2 contains several examples of the observed antimicrobial properties of the three most common phenolic compounds in olive oil, against several micro-organisms. Oleuropein, the first secoiridoid ever isolated, was effective in killing both Gram-positive and Gram-negative pathogenetic bacterial strains and enveloped viruses [109]. The antibacterial effect of oleuropein may derive from the partition of this compound to membranes that contain significant amounts of negatively charged phospholipids in bacterial membranes [110]. One study has presented the role of oleuropein as an 
internal radical scavenger, preventing lipid peroxidation in membranes containing phosphatidylcholine and linoleic acid [111], whilst another study has proposed a superficial location for oleuropein in phospholipid bilayers, where it would act as antioxidant [112]. This is in accordance with a lower antimicrobial activity of oleuropein when compared to hydroxytyrosol (Table 2). This latter compound is effective against mycoplasmal infections at low concentrations [113] and, hydroxytyrosol is absorbed by the human body after virgin oil consumption, as indicated by its presence in urine and plasma samples [114]. Tyrosol is generally less active as antimicrobial agent than the previously mentioned phenolic compounds, it showed nearly no effect on $H$. pylori [108] and concentrations higher than $100 \mathrm{mM}$ were needed to inhibit Lactobacillus plantarum growth [115].

The aldehydes present in olives and olive oil also show antifungal and antibacterial activities. A study has shown that, contrary to most plant secondary metabolites, long chain saturated and unsaturated aldehydes from the olive fruit were more effective against fungi than against Grampositive bacteria [116]. The aliphatic aldehydes hexanal, nonanal, (E)-2-hexenal, (E)-2-heptenal, (E)-2-octenal and (E)-2-nonenal inhibited the growth of Tricophyton mentagrophytes and Microsporum canis at concentrations between 1.9 and $125 \mu \mathrm{g} / \mathrm{mL}$, with the unsaturated aldehydes exhibiting the most broad spectrum of activity [117]. Bisignano et al. [109] suggested that the presence of a double bond on the molecule of aldehydes in olives is important for their antimicrobial properties. The work of Battinelli et al. [117] also showed that (E)-2-octenal and (E)-2-nonenal inhibited elastase activity, thus inhibiting a virulence factor essential for microbial colonization of human epidermis. The same study also showed a low toxicity of olive aldehydes to human reconstructed epidermis, supporting the idea that the use of olives and olive oil in skin diseases may, by the action of these compounds, be effective in the topical treatment of fungal cutaneous infections.

In general, all the studies concerning extracts of olive leaves, fruits and oil, as well as those carried out with the several isolated compounds show the antimicrobial properties of these components.

\section{Spices and Herbs}

Herbs were at the base of Hippocrate's medicine and the knowledge of their properties was used by the Romans, who were responsible for carrying these commodities to the rest of Europe. The herbs of widespread use in Roman times included several species of the family Apiaceae such as dill (Anethum graveolens L.), and of the family Lamiaceae such as rosemary, thyme (mainly Thymus vulgaris L.), and mint (various species of the genus Mentha). The Roman soldier received $c a .880 \mathrm{~g}$ per day of wheat which was cooked with salt and oil to make puls, baked to make "military bread", panis militaris, or double-baked to make hardtack, buccelatum [118]. Additionally, they received $c a .620 \mathrm{~g}$ of various products including vegetables, fruits, nuts and cheese, $c a$. $160 \mathrm{~g}$ of meat or fish, half-pint of sour wine or vinegar, olive oil and salt. Although this diet was quite adequate, the soldiers also used their pay to buy additional foodstuffs, such as fish sauce, spices, wine and vinegar, to improve the variety of their rations [38]. These products, provided by local settlers and merchandisers, probably contained a large number of herbs which are still part of the diet in the Mediterranean area (e.g. thyme, rosemary, mint and dill).

The word lavender originates from the Latin word "lavare" which means "to wash". However, the word "lavare" was also used as a medical term referring to cleansing wounds. This suggests that the lavender, mostly the flower stems of the shrubs of Lavandula angustifolia P. Mill. and some related species (Family Lamiaceae), added to the water of communal baths and personal soaps was used as prophylactic agent against diseases. Lavender was probably added to baths and soaps as disinfectant and to body lotions for fragrance purposes. Herbs and higher plants contain terpenes and terpenoids which have been used as fragrances and flavours for centuries are now known to have a role in the prevention and therapy of diseases, can be used as natural insecticides and antimicrobial agents, as well as food pre-

Table 2. Minimum Inhibitory Concentration (MIC) of Phenol Compounds Present in Olives and Olive Oil to Several MicroOrganisms

\begin{tabular}{|c|c|c|c|}
\hline Phenolic Compound & Micro-Organism & $\operatorname{MIC}(\mu \mathrm{g} / \mathrm{mL})$ & Reference \\
\hline \multicolumn{4}{|l|}{ Simple Phenols } \\
\hline Tyrosol & Lactobacillus plantarum & $>13816$ & [115] \\
\hline \multicolumn{4}{|l|}{ Secoiridoids } \\
\hline Oleuropein & $\begin{array}{l}\text { Hemophilus influenza } \\
\text { Samonella typhi } \\
\text { Staphilococcus aureus }\end{array}$ & $\begin{array}{l}500 \\
125 \\
62.5\end{array}$ & $\begin{array}{l}{[109]} \\
{[109]} \\
{[109]}\end{array}$ \\
\hline
\end{tabular}


servatives [119]. Other compounds, including carotenoids, phenolic compounds and flavonoids have also been isolated from herbs and spices and described to have anti-oxidant and antimicrobial activity [120].

Rosemary is widely used in southern countries of Europe and has been used as a fragrance of food and nutraceutical products, storage compartments, soaps and cosmetic products. Several microorganisms are affected by extracts of rosemary (Table 3; [121]). Crude aqueous and methanolic extracts of rosemary are able to inhibit growth (MIC of 16 and $4 \mathrm{mg} / \mathrm{mL}$, respectively) of Streptococcus sobrinus and the synthesis of the water-insoluble glucan produced by this bacterium during dental plaque formation [122]. The diterpenes extracted from rosemary leaves (carnosol, carnosic acid and rosmadial) affect lipid polymorphism and fluidity of phospholipid membranes [65].

The antimicrobial effect of the essential oils of both cumin (Cuminum cyminum L.; Family Apiaceae) and rosemary was also ascribed to the presence of terpenes $(\alpha-$ pinene; 1,8-cineole and linalool), which are the major constituents of these plants [123].

Thyme has been used as an aromatic plant since ancient times and was largely used in Roman culinary. The most important compounds in its oil extract are the phenols thymol and carvacrol and the terpenes $p$-cymene and $\gamma$ terpinene. Oil extract of thyme is effective against Aspergillus flavus, has a fungitoxic effect against several food contaminating fungi, and is able to arrest aflatoxin B1 production at $0.6 \mu \mathrm{g} / \mathrm{mL}$ [124]. At $0.6 \%$, thyme oil extract also inhibited E. coli O157:H7 growth in minced beef meat [125]. Curiously, the essential oils of several plants and herbs, including thyme, caused an inhibitory effect against herpes simplex virus type 2 , causing a $90 \%$ reduction in plaque formation, but no effect was observed when the oils were added to the cells prior infection with the virus [126].
Several herbs belonging to the family Lamiaceae such as basil (Ocimum basilicum L.), marjoram (Origanum majorana L.), oregano (Origanum vulgare L.), rosemary and thyme, along with other spices and herbs such as clove (Syzygium aromaticum L. Merr. et L. M. Perry Syn Eugenia caryophyllata; Family Myrtaceae), garlic (Allium sativum L.; Family Alliaceae), and horseradish (Armoracia rusticana P.G. Gaertn., B. Mey. \& Scherb.; Family Brassicaceae), inhibit Vibrio parahaemolyticus, that when present in seafood, especially in warm environments, cause gastroenteritis in humans [127]. Reduction of the incubation temperature from $30^{\circ} \mathrm{C}$ to $5^{\circ} \mathrm{C}$ resulted in only little differences of the MIC, which ranged between 0.063 and $2 \%$. Marjoram is also able to kill several common pathogens at MIC ranging 0.069-2.3 $\mathrm{mg} / \mathrm{mL}$ [128].

Gurierrez and co-workers [129] showed that combinations of plant essential oils, including basil, lemon balm, marjoram, oregano, rosemary, sage and thyme, can result in additive antimicrobial effects, thus decreasing the amount of oil required and the adverse sensory impact in food. The antimicrobial activity of a mixed oregano and cranberry extract against $V$. parahaemolyticus was also higher than individual extracts at the same phenolic concentration [130]. One set of phenolic compounds may damage the cellular membranes, increasing the effect of the other set. Furthermore, the survival of this bacterium in the presence of lactic acid was overcome by the combined action of oregano and cranberry extracts added to the acid. The phenolic damage caused to the bacterial membranes, can affect the proton motive force and therefore make the cells more susceptible to acid. Nevertheless, the combinations of essential oils should be tested as the effectiveness may be influenced by the food composition. Films of whey protein isolate, aimed at the food packaging industry, containing $1.0-4.0 \%$ (wt/vol) of oregano or garlic essential oils were able to inhibit growth of E. coli, S. aureus, Salmonella enteritidis, Listeria monocyto-

Table 3. Minimum Inhibitory Concentration (Mic) of Oil Extracts of Cumin, Marjoram, Rosemary and Thyme Against Several Common Pathogens

\begin{tabular}{|c|c|c|c|}
\hline $\begin{array}{c}\text { Cumin } \\
\text { (Cuminum cyminum) }\end{array}$ & $\begin{array}{l}\text { Staphylococcus aureus } \\
\text { Listeria monocytogenes }\end{array}$ & $\begin{array}{l}0.001 \\
0.002\end{array}$ & [123] \\
\hline $\begin{array}{c}\text { Marjoram } \\
\text { (Origanum majorana L.) }\end{array}$ & $\begin{array}{c}\text { Bacillus subtilis } \\
\text { Enterococcus faecalis } \\
\text { Escherichia coli } \\
\text { Klebsiella pneumoniae } \\
\text { Salmonella choleraensius } \\
\text { Staphylococcus aureus }\end{array}$ & $\begin{array}{c}0.069 \\
2.3 \\
0.920 \\
0.920 \\
0.920 \\
0.782\end{array}$ & [128] \\
\hline $\begin{array}{c}\text { Rosemary } \\
\text { (Rosemarinus officinalis L.) }\end{array}$ & $\begin{array}{c}\text { B. subtilis } \\
\text { E. faecalis } \\
\text { E. coli } \\
\text { K. pneumoniae } \\
\text { S. aureus } \\
\text { C. albicans } \\
\text { Streptococcus sobrinus }\end{array}$ & $\begin{array}{c}2.5-20 \\
2.5-20 \\
10-20 \\
10-20 \\
5-20 \\
2.5-10 \\
4-16 \mathrm{mg} / \mathrm{mL}\end{array}$ & $\begin{array}{c}{[121]} \\
{[65]}\end{array}$ \\
\hline $\begin{array}{c}\text { Thyme } \\
\text { (Thymus vulgaris L.) }\end{array}$ & Aspergillus flavus & 0.007 & [124] \\
\hline
\end{tabular}


genes and Lactobacillus plantarum cells [131]. An increase in shelf-life of rye bread could be also achieved by active packaging with allyl isothiocyanate, the active component of mustard essential oil that provides the "bite" of yellow and brown mustard [132].

In a review by Burt, the mode of action of essential oils as antibacterial agents was discussed [133]. Among the possible mechanisms conferring antimicrobial properties to essential oils are the following: damage of the cell wall, cytoplasmic membrane and membrane proteins; leakage of ions and other cell content; and depletion of proton motive force. However, as the oils contain several compounds, the antimicrobial effect can be the result of several mechanisms acting upon different cell components.

\section{The Peculiar Castor Oil, the Seed Oil of Ricinus commu- nis L. (Family Euphorbiaceae)}

In 2003, Charlwood [134] pointed out that Herodotus [3] who is widely known in malariology for describing the use of mosquito nets (impregnated with fish odour) and towers to avoid mosquito bites may, inadvertently, also have described the first known use of a repellent lamp against mosquitoes. According to Charlwood, Herodotus states: "The Egyptians who live in the marsh-country used an oil extracted from the castor-oil plant (consisting primarily of ricinoleic acid). This plant, which grows wild in Greece, they call Kiki, and the Egyptian variety is very prolific and has a disagreeable smell. (...) The country is infested by swarms of gnats [mosquitoes], and the people have invented various methods of dealing with them (...)". In fact, a study from 2003 has reported the insecticidal properties of Ricinus communis $\mathrm{L}$ foliage flavonoids against a species of Coleoptera [135].

\section{Honey}

Natural sun drying was probably the most common method to preserve food produce such as cereals, fruits, vegetables, spices, seeds and fish, especially in the Mediterranean area. In this process, water necessary for the growth of micro-organisms is removed from the food by osmotic action. Furthermore, a hard outer-layer is generally created which retards the entrance of micro-organisms e.g. when a plum is transformed into a prune or a grape becomes a raisin. In these cases, the sugar concentration in the product increases to microbial inhibitory concentrations. During the Roman period, honey was the only sugar known. Jars of fruits preserved in honey have been found in Pompeii. Honey contains sugars (mainly fructose and glucose), minerals (e.g. potassium, calcium and manganese), phenolic and flavonoid compounds. The reduced moisture content of honey is an important factor to prevent its fermentation and granulation.

Honey has been proven to be an effective antimicrobial agent against $H$. pylori, $S$. aureus, B. subtilis, Candida tropicalis and $C$. albicans [136] and also against methicillinresistant $S$. aureus [137]. Strains of the latter bacterium were not detectable after $24 \mathrm{~h}$ in contact with honey, which may be applied topically to wounds. The antimicrobial properties of honey irradiated at 25 and $50 \mathrm{kGy}$ and stored in a cool dark place, could be maintained for up to two years [138]. When $S$. interitidis was incubated with honey at dilutions up to $1: 8$, bacterial adherence to intestinal epithelial cells was prevented in vitro, but attachment occurred when epithelial cells were incubated with honey [139]. The prevention of bacterial adherence was, therefore, the result of an effect of honey on S. interitidis cells.

\section{Copper, Silver and Sulphur}

Copper was used throughout the Roman Empire in water piping systems, cutlery, and cookware to improve public health, long before the existence of micro-organisms was acknowledged. Metallic copper was also added to medicinal plasters and pills in addition to plant and animal compounds [140].

Nowadays, it is known that pure copper is able to inhibit a $10^{7} \mathrm{cfu} / \mathrm{mL}$ population of meticillin-resistant Staphylococcus aureus (MRSA) within $45 \mathrm{~min}$ [141] as well as E. coli [142]. Recent studies have shown that copper surfaces are much more effective to completely kill the three most prevalent strains of epidemic MRSA in the UK than stainless steel surfaces [141]. On the latter surface, viable organisms were still present after $72 \mathrm{~h}$ at $22^{\circ} \mathrm{C}$. Similar results had been observed about 20 years ago, showing that streptococci and staphylococci could grow on stainless steel but not on brass doorknobs [143]. However, stainless steel is still the preferred material by hospital administrations. If copper and brass are to be re-introduced in hospital and health-care environments as an antibacterial surface, common cleaning products and procedures should nonetheless be re-tested as the most often used products may react with copper [144].

Along with copper, silver was used by the Greeks and Romans to keep water. Phoenicians preferred silver containers to preserve water, wine and vinegar, and carried them during their long journeys in the Mediterranean area. This metal was used by the Romans in cutlery and to make dishes and cups to prevent diseases and wealthy people used silver vessels to keep food. Silver acts against a broad spectrum of bacteria, yeasts and fungi strains. The antimicrobial activity is due to the binding of the positively charged silver ions with negatively charged microbial cells (leading to membrane ruptures, protein denaturation and cell death) and to reaction with the sulfhydryl groups on cell walls leading to interferences in the respiration of microbial cells [145, 146].

Nowadays, the application of silver coatings has spread to implanted devices to prevent infections in tissue pockets, dressings, medicine textiles and films [147]. Silver is also used in tablets for rapid water purification. These tablets have been developed because of the presence of military personnel from developed countries in third world conflicts and by tourism in remote areas. Silver based tablets present advantages over decolourised iodine tincture as some people are allergic to iodine and thyroid abnormalities related to iodine have been reported [148].

Although the European drinking water directive 98/83/ EC does not state the limit for silver, many European countries limit its concentration to $0.05-0.1 \mathrm{mg} / \mathrm{L}$. In the US, the Environmental Protection Agency limits the concentrations of copper to $1.0 \mathrm{mg} / \mathrm{L}$ and of silver to $0.1 \mathrm{mg} / \mathrm{L}$.

Wine can easily turn to vinegar within 6 months after being made in the absence of preservatives. Sulphites have been added to wines since ancient times to preserve wine and 
even today most of the wines produced contain these compounds. The Greeks and the Romans used sulphur candles to sterilise wine barrels and amphorae, added egg's yolk, mustard seed or other sulphur containing substances. Sulphur can both prevent wine oxidation and growth of undesired microbes. A recently published paper demonstrated that to control the yeast Dekkera bruxellensis, which is responsible for considerable economic losses in the wine industry, relatively high doses of molecular sulphur dioxide is required [149]. The yeast presented three survival patterns and was able to resume growth after an initial decline during which no colonies are detected in agar plates.

\section{CONCLUDING REMARKS}

In the 1950's it was remarked that the peoples from the Mediterranean area presented a rate of cancer incidence much lower than the rest of the developed world countries. By the 1970's, results from two decades of both epidemiological and biochemical studies confirmed the beneficial health effects of the typical Mediterranean edible products, and the benefits of the Mediterranean diet were recognised [40]. Subsequent studies, such as those referred in this review have clarified the action mechanisms of the various products and components used during millennia in this area. We consider that humanity can learn from the ancient civilizations to prevent cardiovascular diseases, obesity and problems associated with it, and cancer. Furthermore, the use of natural compounds and preservatives may reduce the use of synthetic chemicals thus allowing for the enhancement of human health, decrease of environmental risks, and the reduction in bacterial resistance to antimicrobials.

\section{ACKNOWLEDGEMENTS}

The authors wish to thank Fundação para a Ciência e a Tecnologia, Portugal, for financial support through the grant SFRH/BPD/25259/2005 awarded to M.J.Caramujo and through the program Ciência 2007 supporting C.C.C.R. de Carvalho.

\section{REFERENCES}

[1] Chain E, Florey HW, Gardner AD, et al. Penicillin as a chemotherapeutic agent. Lancet 1940; 236(6104): 226-8.

[2] Dyke KG, Jevons, Parker MT. Penicillinase production and intrinsic resistance to penicillins in Staphylococcus aureus. Lancet 1966; 287(7442): 835-8.

[3] Herodotus. The history of Herodotus (440 B.C.). The Internet Classics Archive; 1994-2000 [Cited Aug 27 2008]. Available from: http://classics.mit.edu/Herodotus/history.html

[4] Forster ES. Trees and plants in Herodotus. Class Rev 1942; 56(2): 57-63.

[5] Hippocrates. Corpus Hippocraticum (400 B.C.). The Internet Classics Archive; 1994-2000 [Cited Aug 27 2008]. Available from: http://classics.mit.edu/Browse/browse-Hippocrates.html

[6] Theophrastus. Enquiry into plants, Books 1-5. Translated by A. F. Hort. The Loeb Classical Library, Harvard University Press: Boston 1916; 504.

[7] Theophrastus. Enquiry into Plants, Books 6-9: Treatise on odours; Concerning weather signs. Translated by A. F. Hort. The Loeb Classical Library, Harvard University Press: Boston 1916; 520.

[8] Bostock J, Riley HT Eds. Pliny the Elder, The natural history. Book XV: The natural history of the fruit trees. Taylor and Francis, London, UK, 1855. The Perseus Digital Library, Tufts University; [Cited Aug 27 2008]. Available from: http://www.perseus.tufts.edu/ cgi-bin/ptext?doc=Perseus\%3Atext\%3A1999.02.0137\&query=toc: head $\% 3 \mathrm{D} \% 23873$.
[9] Gunther RT Ed. The Greek herbal of Dioscorides, Hafner: New York, NY 1959 (reprint of 1933 ed); 243.

[10] Singer C. The herbal in antiquity and its transmission to later ages. Hellenic Stud 1927; 47(1): 1-52.

[11] Jackson WA. A short guide to humoral medicine. Trends Pharmacol Sci 2001; 22(9): 487-9.

[12] Nasr SH. "Avicenna". Encyclopædia Britannica Online [homepage on the Internet]. Chicago, IL: Encyclopædia Britannica, Inc [updated 2007; Cited August 28 2008]. Available from: http://www. britannica.com/EBchecked/topic/45755/Avicenna

[13] All species and its family names presented in this paper follow the taxonomic updates in The Species 2000 \& ITIS Catalogue of Life [homepage on the Internet]. The Integrated Taxonomic Information System [updated from 2006 March to 2007 November according to species; cited 2008 October 21). Available from: http://www. catalogueoflife.org/annual-checklist/2008.

[14] Piarroux R, Millon L, Bardonnet K, Vagner O, Koenig H. Are live Saccharomyces yeasts harmful to patients? Lancet 1999; 353(9167): 1851-2.

[15] Nielsen H, Stenderup J, Bruun B. Fungemia with Saccharomycetaceae. Report of four cases and review of the literature. Scand J Infect Dis 1990; 22(5): 581-4.

[16] Posteraro B, Sanguinetti M, Romano L, Torelli R, Novarese L, Fadda G. Molecular tools for differentiating probiotic and clinical strains of Saccharomyces cerevisiae. Int J Food Microbiol 2005; 103(3): 295-304.

[17] Fredenucci I, Chomarat M, Boucaud C, Flandrois JP. Saccharomyces boulardii fungemia in a patient receiving Ultralevure therapy. Clin Infect Dis 1998; 27(1): 222-3.

[18] Rijnders BJ, Van Wijngaerden E, Verwaest C, Peetermans WE. Saccharomyces fungemia complicating Saccharomyces boulardii treatment in a non-immunocompromised host. Intensive Care Med 2000; 26(6): 825.

[19] Farber JM, Peterkin PI. Listeria monocytogenes, a food-borne pathogen. Microbiol Rev 1991; 55: 476-511.

[20] Schuchat A, Swaminathan B, Broome CV. Epidemiology of human listeriosis. Clin Microbiol Rev 1991; 4: 169-83.

[21] Poyart-Salmeron C, Carlier C, Trieu-Cuot P, Courtieu A-L, Courvalin P. Transferable plasmid-mediated antibiotic resistance in Listeria monocytogenes. Lancet 1990; 335: 1422-6.

[22] Quentin C, Thibaut MC, Horovitz J, Bebear C. Multiresistant strain of Listeria monocytogenes in septic abortion. Lancet 1990; 336: 375 .

[23] Charpentier E, Courvalin P. Antibiotic resistance in Listeria spp. Antimicrob Agents Chemother 1999; 43(9): 2103-8.

[24] Moellering-Jr RC, Graybill JR, McGowan-Jr JE, Corey L. Antimicrobial resistance prevention initiative - an update: proceedings of an expert panel on resistance. Am J Med 2007; 120(7): S4-S25.

[25] Norrby SR, Nord CE, Finch R. Lack of development of new antimicrobial drugs: a potential serious threat to public health. Lancet Infect Dis 2005; 5: 115-9.

[26] Projan SJ. Why is big Pharma getting out of antibacterial drug discovery? Curr Opin Microbiol 2003; 6: 427-30.

[27] Skovgaard N. New trends in emerging pathogens. Int J Food Microbiol 2007; 120(3): 217-24.

[28] Ames BM. Dietary carcinogens and anticarcinogens: oxygen radical and degenerative diseases. Science 1983; 221(4617): 1256-63.

[29] Park EH, Chang HH, Cha YN. Induction of hepatic tumors with butylated hydroxyanisole in the self-fertilizing hermaphroditic fish Rivulus ocellatus marmoratus. JPN J Cancer Res 1990; 81(8): 73841.

[30] Shirai T, Fukushima S, Ohshima M, Masuda A, Ito N. Effect of butylated hydroxyanisole, butylated hydroxytoluene, and $\mathrm{NaCl}$ on gastric carcinogenesis initiated with methyl-N'-nitro-N-nitro-nnitrosoguanidine in F344 rats. J Natl Cancer Inst 1984; 72(5): 118998.

[31] FASEB. Evaluation of evidence for the carcinogenicity of butylatedhydroxyanisole (BHA). Prepared for the Center for Food Safety and Applied Nutrition, Food and Drug Administration. Federation of American Societies for Experimental Biology. FDA Contract No. 223-92-2185. Department of Health and Human Services: Washington DC; 1994.

[32] Di Giovacchino L. Technological aspects. In: Hardwood J, Aparicio R Eds. Handbook of olive oil. Analysis and properties. Aspen Publications, Gaithersburg: Maryland 2000; 17-59. 
[33] Margaritis E, Jones M. Olive oil production in Hellenistic Greece: the interpretation of charred olive remains from the site of Tria Platania, Macedonia, Greece (fourth-second century B.C.). J Veg Hist Archaeobot 2008; 17(4): 393-401.

[34] Galilia E, Stanley DJ, Sharvita J, Weinstein-Evronc M. Evidence for earliest olive-oil production in submerged settlements off the carmel coast, Israel. J Archaeol Sci 1997; 24(12): 1141-50.

[35] Riley FR. Olive oil production on bronze age Crete: nutritional properties, processing methods and storage life of Minoan olive oil. Oxf J Archeol 2002; 21(1): 63-75

[36] Vossen P. Olive oil: history, production, and characteristics of the World's classic oils. Hort Sci 2007; 42(5): 1093-100.

[37] Agriculture and Rural Development [homepage on the internet] European Union agricultural product quality policy, European Commission; [updated 2008 Oct 15; cited 2008 Oct 21]. Available from: http://ec.europa.eu/agriculture/foodqual/quali1_en.htm

[38] Roth JP. The logistics of the Roman army at war (264 B.C. - A.D. 235) In: Harris WV, Ed. Columbia studies in the Classical Tradition Leiden, Boston: Köln 1999; 23: 399.

[39] Boylan M. Hippocrates (c. 450 BCE to 380 BCE.). The Internet Enciclopedia on Phylosophy. Marymount University; 2006 [Cited Oct 21 2008]. Available from: http://www.iep.utm.edu/h/hippocra. htm

[40] Keys A, Keys M. How to eat well and stay well, the Mediterranean way. Doubleday: New York, NY. 1975; 230.

[41] Parthasarathy S, Khoo JC, Miller E, Witztum JL, Steinberg D. Low density lipoprotein rich in oleic acid is protected against oxidative modification: Implication for dietary prevention of atherosclerosis. Proc Natl Acad Sci USA 1990; 87(10): 3894-8.

[42] Owen RW, Giacosa A, Hull WE, et al. The antioxidant/anticancer potential of phenolic compounds isolated from olive oil. Eur J Cancer 2000; 36(10): 1235-47.

[43] Alarcon de la Lastra C, Barranco MD, Motilova V, Herrerias KM. Mediterranean diet and health: biological importance of olive oil. Curr Pharm Des 2001; 7(10): 933-50.

[44] Moreno JJ. Effect of olive oil minor components on oxidative stress and arachidonic acid mobilization and metabolism by macrophages RAW 264.7. Free Radic Biol Med 2003; 35(9): 1073-81.

[45] Middleton E, Kandaswari C. Effects of flavonoids on immune and inflamatory cell functions. Biochem Pharmacology 1992; 43(6): 1167-79.

[46] Laughton MJ, Evans PJ, Moroney MA, Hoult JRS, Halliwell B. Inhibition of mammalian 5-lipoxygenase and cyclo-oxigenase by flvonoids and phenolic dietary additives. Relationship to antioxidant activity and to iron io-reducing ability. Pharmacol 1991; 42(9): 1673-81.

[47] Frost Larsen L, Jespersen J, Marckmann P. Are olive oil diets antithrombotic? Diets enriched with olive oil, rapeseed, or sunflower oil affect post-prandial factor VII differently. Am J Clin Nutr 1999; 70(6): $976-82$

[48] Petroni A, Blasevich M, Salami M, Papini N, Montedoro GF, Galli C. Inhibition of platelet aggregation and eicosanoid production by phenolic compounds of olive oil. Thromb Res 1995; 78(2): 151-60.

[49] Stavric B. Role of chemopreventers in human diet. Clin Biochem 1994; 27(5): 319-32.

[50] Ramirez-Tortosa MC, Urbano G, Lopez-Jurado M et al. Extravirgin olive oil increases the resistance of LDL to oxidation more than refined olive oil in free-living men with peripheral vascular disease. J Nutr 1999; 129(12): 2177-83.

[51] Lee A, Thurnham DI, Chopra C. Consumption of tomato products with olive oil but not sunflower oil increases the antioxidant activity of plasma. Free Radical Biol Med 2000; 29(10): 1051-5.

[52] Rocio de la Puerta VRG, Hoult JRS. Inhibition of leukocyte 5lipoxygenase by phenolics from virgin olive oil. Biochem Pharmacol 1999; 57 (4): 445-9.

[53] Manna CP, Galletti P, Cucciolla V, Moltedo O, Leone A, Zappia $\mathrm{V}$. The effect of the olive oil polyphenol (3,4-dihydroxyphenyl)ethanol counteracts reactive metabolite-induced cytotoxicity in Caco-2 cells. J Nutr 1997; 127(2): 286-92.

[54] Nakayama T. Suppression of hydroperoxide-induced cytotoxicity by polyphenols. Cancer Res 1994; 54 (Suppl): S1991-3.

[55] Newmark HL. Squalene, olive oil, and cancer risk: A review and hypothesis. Cancer Epidemiol Biomarkers Prev 1997; 6(12): 11013.

[56] Mangena T, Muyima N. Comparative evaluation of the antimicrobial activities of essential oils of Artemisia afra, Pteronia incana and Rosmarinus officinalis on selected bacteria and yeast strains. Lett Appl Microbiol 1999; 28(4): 291-6.

[57] Dorko C. Antioxidants used in foods. Food Technol 1994; 48(4): 33

[58] Almeida-Doria RF, Regitano-D'Arce MAB. Antioxidant activity of rosemary and oregano ethanol extracts in soybean oil under thermal oxidation. Ciência e Tecnologia dos Alimentos 2000; 20(2): 2-15.

[59] Hidalgo PJ, Ubera JL, Tena MT, Valcarcel M. Determination of the carnosic acid content in wild and cultivated Rosmarinus officinalis. J Agri Food Chem 1998; 46(7): 2624-7.

[60] Celktas OY, Bedir E, Sukan VF. In vitro antioxidant activities of Rosmarinus officinalis extracts treated with supercritical carbon dioxide. Food Chem 2007; 101(4): 1457-64.

[61] Singletary KW. Rosemary extract and carnosol stimulate rat liver glutathione-S-transferase and quinone reductase activities. Cancer Lett 1996; 100: 139-44.

[62] Dorrie J, Sapala K, Zunino SJ. Carnosol-induced apoptosis and downregulation of Bcl-2 in B-lineage leukemia cells. Cancer Lett 2001; 170(1): 33-9.

[63] Offord EA, Gautier JC, Avanti O, et al. Photoprotevtive potential of lycopene, $\beta$-carotene, vitamin $\mathrm{E}$, vitamin $\mathrm{C}$ and carnosic acid in UV-A-irradiated human skin fibroblast. Free Radic Biol Med 2002; 32(12): 1293-303.

[64] Subbaramaiah K, Cole PA, Dannenberg AJ. Retinoids and carnosol suppress cyclooxygenase-2 transcription by CREB-binding protein/p300-dependent and -independent mechanisms. Cancer Res 2002; 62(9): 2522-30.

[65] Pérez-Fons L, Aranda FJ, Guillén J, Villalaín J, Micol V. Rosemary (Rosmarinus officinalis) diterpenes affect lipid polymorphism and fluidity in phospholipid membranes. Arch Biochem Biophys 2006; 453(2): 224-36.

[66] Venskutonis P, Gruzdiené R, Tirzite D, Tirzitis G. Assessment of antioxidant activity of plant extracts by different methods. ISHS Acta Horticulturae 677: III WOCMAP Congress on Medicinal and Aromatic Plants, 3: Perspectives in Natural Product Chemistry; 2002.

[67] Danilenko M, Wang Q, Wang X, Levy J, Sharoni Y, Studzinski GP. Carnosic acid potentiates the antioxidant and prodifferentiation effects of 1a,25-dihydroxyvitamin D3 in leukemia cells, but does not promote elevation of basal level of intracellular calcium. Cancer Res 2003; 63: 1325-32.

[68] Van Blitterswijk WJ, De Veer G, Krol JH, Emmelot P. Comparative lipid analysis of purified plasma membranes and shed extracellular membrane vesicles from normal murine thymocytes and leukemic GRSL cells. Biochim Biophys Acta 1982; 688(2): 495-504.

[69] Hanuš LO, Řezanka T, Dembitsky VM, Moussaieff A. Myrrh Commiphora chemistry. Biomed Papers 2005; 149(1): 3-28.

[70] Ali NA, Wurster M, Arnold N, et al. Chemical composition and Biological activities of essential oils from the oleogum resins of three endemic Soqotraen Boswellia species. Rec Nat Prod 2008; 2(1): 6-12.

[71] Tucker AO. Frankincense and myrrh. Econ Bot 1986; 40(4): 42533.

[72] El Ashry ES, Rashed N, Salama OM, Saleh A. Components, therapeutic value and uses of myrrh. Pharmazie 2003; 58(3): 163-8.

[73] Gopal K, Saran RK, Nityanand S. Clinical trial of ethyl acetate extract of gum gugulu (gugulipid) in primary hyperlipidemia. J Assoc Phys India 1986; 34(4): 249-51.

[74] Mesrob B, Nesbitt C, Misra R, Pandey RC. High-performance liquid chromatographic method for fingerprinting and quantitative determination of E- and Z-guggulsterones in Commiphora mukul resin and its products. J Chromatogr B Biomed Sci Appl 1988; 720(1-2): 189-96.

[75] Nagarajan M, Waszkuc TW, Sun J. Simultaneous determination of E- and Z-guggulsterones in dietary supplements containing Commiphora mukul extract (guggulipid) by liquid chromatography. J AOAC Int 2001; 84(1): 24-8.

[76] Cui J, Huang L, Zhao A. Guggulsterone is a farnesoid X antagonist in coactivator association assays but acts to enhance transcription of bile salt export pump. J Biol Chem 2003; 278 (12): 10214-20.

[77] Urizar NL, Liverman AB, Dodds DT, et al. A natural product that lowers cholesterol as an antagonist ligand for FXR. Science 2002 296(5573): 1703-6.

[78] El-Ashmawy IM, Ashry KM, El-Nahas AF, Salama OM. Protection by turmeric and myrrh against liver oxidative damage and 
genotoxicity induced by lead acetate in mice. Basic Clin Pharmacol Toxicol 2006; 98(1): 32-7.

[79] Kimura I, Yoshikawa M, Kobayashi S. New triterpenes, myrrhanol A and myrrhanone A, from guggul-gum resins, and their potent anti-inflammatory effect on adjuvant-induced air-pouch granuloma of mice. Bioorg Med Chem Lett 2001; 11(8): 985-9.

[80] Fattorusso E, Santacroce C, Xaasan CB. Dammarane triterpenes from the resin of Boswellia freerana. Phytochemistry 1985; 24(5): 1035-6.

[81] Hostanska K, Daum G, Saller R. Cytostatic and apoptosis-inducing activity of boswellic acids towards malignant cell lines in vitro. Anticancer Res 2002; 22(5): 2853-62.

[82] Vieira O, Escargueil-Blanc I, Meilhac O, et al. Effect of dietary phenolic compounds on apoptosis of human cultured endothelial cells induced by oxidized LDL. Br J Pharmacol 1998; 123(3): 56573.

[83] Visioli F, Galli C. Antitheroganic Components of Olive Oil. Curr Atheroscler Rep 2001; 3(1): 64-7.

[84] Fito M, Covas MI, Lamuela-Raventos RM, et al. Protective effect of olive oil and its phenolic compounds against low density lipoprotein oxidation. Lipids 2000; 35(6): 633-8.

[85] Fito M, Covas MI, Lamuela-Raventos RM, Vila J, de la Torre C, Marrugat J. Olive oil and inhibition of low density lipoprotein oxidation. Role of phenolic compounds. Med Clin 2000; 115(5): 1669.

[86] Visioli F, Bellomo G, Galli C. Low density lipoprotein oxidation is inhibited in vitro by olive oil constituents. Atherosclerosis 1995; 117(1): $25-32$

[87] Salami M, Galli C, De Angelis L, Visioli F. Formation of F2isoprostanes in oxidized low density lipoprotein: inhibitory effects of hydroxytyrosol. Pharmacol Res 1995; 31(5): 275-9.

[88] Ragione FD, Cucciolla V, Borriello A, et al. Hydroxytyrosol, a natural molecule occurring in olive oil, induces cytochrome cdependent apoptosis. Biochem Biophys Res Commun 2000; 278(3): 733-9.

[89] Luchetti F. Importance and future of olive oil in the world market an introduction to olive oil. Eur J Lipid Sci Technol 2002; 104(910): 559-63.

[90] Johnston HW. The Private Life of the Romans, The Private Life of the Romans. Chapter 8: Food and Meals (Revised by Mary Johnston Scott). Foresman and Company (1903, 1932), pp. 348. Forum Romanum c2006 [Cited September 26 2008]. Available from: http://www.forumromanum.org/life/johnston 8.html\#289

[91] Smith DA, Stretton JE. Acidified Foods. Food Processing for Entrepreneurs Series, G1685. Foods and Nutrition Safety, January 2007; 3 pp. University of Nebraska-Lincoln Extension, Institute of Agriculture and Natural Resources; 2006 [updated 2007; Cited September 26 2008]. Available from http://www.ianrpubs.unl.edu/ epublic/pages/publicationD.jsp?publicationId=681

[92] Gulfraz M, Parveen R, Musseddque Y, Nisar U, Ithisham M, Rehman S. Determination of essential oil content of wild olive and its comparison with olive oil. Ethnobot Leaflets 2006; 10: 1-12.

[93] Dilika F, Bremner PD, Meyer JJM. Antibacterial activity of linoleic and oleic acids isolated from Helichrysum pedunculatum: a plant used during circumcision rites. Fitoterapia 2000; 71(4): 450-2.

[94] Brul S, Coote P. Preservative agents in foods. Mode of action and microbial resistance mechanisms. Int J Food Microbiol 1999; 50(12): $1-17$.

[95] Alves MR, Cunha SC, Amaral JS, Pereira JA, Oliveira MB. Classification of PDO olive oils on the basis of their sterol composition by multivariate analysis. Anal Chim Acta 2005; 549(1-2): 166-78.

[96] Tuck KL, Hayball PJ. Major phenolic compounds in olive oil: metabolism and health effects. J Nutr Biochem 2002; 13(11): 63644.

[97] Ryan D, Robards K, Lavee S. Changes in phenolic content of olive during maturation. Int J Food Sci Technol 1999; 34(3): 265-74.

[98] Saija A, Uccella N. Olive biophenols: functional effects on human wellbeing. Trends Food Sci Technol 2000; 11(9-10): 357-63.

[99] Ortega-García F, Blanco S, Peinado MA, Peragón J. Polyphenol oxidase and its relationship with oleuropein concentration in fruits and leaves of olive (Olea europaea) cv. 'Picual' trees during fruit ripening. Tree Physiol 2008; 28(1): 45-54.

[100] Amiot MJ, Fleuriet A, Macheix JJ. Importance and evolution of phenolic compounds in olive during growth and maturation. J Agric Food Chem 1996; 34(5): 823-6.
[101] García A, Brenes M, García P, Romero C, Garrido A. Phenolic content of commercial olive oils. Eur Food Res Technol 2003; 216(6): 520-5.

[102] Bianco A, Serrilli AM, Melchioni C. Molecular composition and quality/taste of olive oil: monoterpenes and natural phenols. ARKIVOC 2007; 7 : 146-56

[103] Pliny the Elder, The Natural History. Translated by Bostock J, Riley HT. The Natural History of Pliny: Amurca of Olives Twenty-one Remedies, 1856, pp. 486. The Perseus Digital Library, Tufts University; [Cited Aug 27 2008]. Available from: http://www perseus.tufts.edu/cgi-bin/ptext?doc=Perseus\%3Atext\%3A1999.02. $0137 \&$ query=toc:head $\% 3 \mathrm{D} \% 23873$

[104] Cato M. De Agricultura (On Agriculture), Loeb Classical Library, Harvard University Press, Boston, 1934; pp 93-97. Thayer B, University of Chicago; c2002 [Cited Aug 27 2008]. Available from: http://penelope.uchicago.edu/Thayer/E/Roman/Texts/Cato/De_Agri cultura/F*.html

[105] Gonçalves C, Lopes M, Alves M, Isabel Belo. Use of olive mill wastewater by lipolytic yeasts. J Biotechnol 2007; 131 (Suppl): S133-87.

[106] Medina E, de Castro A, Romero C, Brenes M. Comparison of the concentration of phenolic compounds in olive oils and other plant oils: correlation with antimicrobial activity. J Agric Food Chem 2006; 54(14): 4954-61.

[107] Serra AT, Matias AA, Nunes AVM, et al. In vitro evaluation of olive- and grape-based natural extracts as potential preservatives for food. Innov Food Sci Emerg Technol 2008; 9(3): 311-319.

[108] Romero C, Medina E, Vargas J, Brenes M, de Castro A. In vitro activity of olive oil polyphenols against Helicobacter pylori. J Agric Food Chem 2007; 55(3): 680-6.

[109] Bisignano G, Tomaino A, Lo Cascio R, Crisafi G, Uccella N, Saija A. On the in-vitro antiomicrobial activity of oleuropein and hydroxytyrosol. J Pharm Pharmacol 1999; 31(8): 971-4.

[110] Caturla N, Pérez-Fons L, Estepa A, Micol V. Differential effects of oleuropein, a biophenol from Olea europaea, on anionic and zwiterionic phospholipid model membranes. Chem Phys Lipids 2005; 137(1-2): 2-17.

[111] Saija A, Trombetta D, Tomaino A, et al. "In vitro" evaluation of the antioxidant activity and biomembrane interaction of the plant phenols oleuropein and hydroxytyrosol. Int J Pharm 1998; 166(2): 123-33.

[112] Paiva-Martins F, Gordon MH, Gameiro P. Activity and location of olive oil phenolic antioxidants in liposomes. Chem Phys Lipids 2003; 124(1): 23-36

[113] Furneri PM, Piperno A, Sajia A, Bisignano G. Antimycoplasmal activity of hydroxytyrosol. Antimicrob Agents Chemother 2004; 48(12): 4892-94

[114] Miro-Casas E, Covas MI, Farre M, et al. Hydroxytyrosol disposition in humans. Clin Chem 2003; 49(6): 945-52.

[115] Landete JM, Curiel JA, Rodríguez H, de las Rivas B, Muñoz R. Study of the inhibitory activity of phenolic compounds found in olive products and their degradation by Lactobacillus plantarum strains. Food Chem 2008; 107(1): 320-6.

[116] Kubo A, Lunde S, Kubo I. Antimicrobial activity of the Olive oil flavor compounds. J Agric Food Chem 1995; 43(6): 1629-33.

[117] Battinelli L, Daniele C, Cristiani M, Bisignano G, Saija A, Mazzanti G. In vitro antifungal and anti-elastase activity of some aliphatic aldehydes from Olea europaea L. fruit. Phytomedicine 2006; 13(8): 558-563.

[118] Kehne P. In: Erdkamp P Ed. A companion to the roman army. Blackwell Publishing Ltd: Malden 2007; 323-38.

[119] de Carvalho CCCR, da Fonseca MMR. Carvone: why and how should one bother to produce this terpene. Food Chem 2006; 95(3): 413-422.

[120] Dadalioglu I, Evrendilek G. Chemical compositions and antibacterial effects of essential oils of Turkish oregano (Origanum minutiflorum), bay laurel (Laurus nobilis), Spanish lavender (Lavandula stoechas L.), and fennel (Foeniculum vulgare) on common foodborne pathogens. J Agric Food Chem 2004; 52(26): 8255-60.

[121] Celiktas OY, Kocabas EEH, Bedir E, Sukan FV, Ozek T, Baser KHC. Antimicrobial activities of methanol extracts and essential oils of Rosmarinus officinalis, depending on location and seasonal variations. Food Chem 2007; 100(2): 553-9.

[122] Tsai P-J, Tsai T-H, Ho S-C. In vitro inhibitory effects of rosemary extracts on growth and glucosyltransferase activity of Streptococcus sobrinus. Food Chem 2007; 105(1): 311-6. 
[123] Gachkar L, Yadegari D, Rezaei MB, Taghizadeh M, Astaneh SA, Rasooli I. Chemical and biological characteristics of Cuminum cyminum and Rosmarinus officinalis essential oils. Food Chem 2007; 102(3): 898-904.

[124] Kumar A, Shukla R, Singh P, Prasad CS, Dubey NK. Assessment of Thymus vulgaris L. essential oil as a safe botanical preservative against post harvest fungal infestation of food commodities. Innov Food Sci Emerg Technol 2008; 9(4): 575-80.

[125] Solomakos N, Govaris A, Koidis P, Botsoglou N. The antimicrobial effect of thyme essential oil, nisin and their combination against Escherichia coli $\mathrm{O} 157: \mathrm{H} 7$ in minced beef during refrigerated storage. Meat Sci 2008; 80(2): 159-66.

[126] Koch C, Reichling J, Schneele J, Schnitzler P. Inhibitory effect of essential oils against herpes simplex virus type 2. Phytomedicine 2008; 15(1-2): 71-8

[127] Yano Y, Satomi M, Oikawa H. Antimicrobial effect of spices and herbs on Vibrio parahaemolyticus. Int J Food Microbiol 2006; 111(1): 6-11.

[128] Busatta C, Vidal RS, Popiolski AS, et al. Cansian RL. Application of Origanum majorana L. essential oil as an antimicrobial agent in sausage. Food Microbiol 2008; 25(1): 207-11.

[129] Gutierrez J, Barry-Ryan C, Bourke P. The antimicrobial efficacy of plant essential oil combinations and interactions with food ingredients. Int J Food Microbiol 2008; 124(1): 91-7.

[130] Lin YT, Labbe RG, Shetty K. Inhibition of Vibrio parahaemolyticus in seafood systems using oregano and cranberry phytochemical synergies and lactic acid. Innov Food Sci Emerg Technol 2005; 6(4): 453-8

[131] Seydim AC, Sarikus G. Antimicrobial activity of whey protein based edible films incorporated with oregano, rosemary and garlic essential oils. Food Res Int 2006; 39(5): 639-644.

[132] Nielsen PV, Rios R. Inhibition of fungal growth on bread by volatile components from spices and herbs, and the possible application in active packaging, with special emphasis on mustard essential oil. Int J Food Microbiol 2000; 60(2-3): 219-29.

[133] Burt S. Essential oils: their antibacterial properties and potential applications in foods - a review. Int J Food Microbiol 2004; 94(3): 223-53.

[134] Charlwood D. Did Herodotus describe the first airborne use of mosquito repellents? Trends Parasitol 2003; 19(12): 555-6.

[135] Upasani SM, Kotkar HM, Mendki PS, Maheshwari VL. Partial characterization and insecticidal properties of Ricinus communis $\mathrm{L}$ foliage flavonoids. Pest Manage Sci 2003; 59(12): 1349-54.
[136] Küçük M, Kolayl S, Karaoğlu S, Ulusoy E, Baltac C, Candan F. Biological activities and chemical composition of three honeys of different types from Anatolia. Food Chem 2007; 100(2): 526-34.

[137] Maeda Y, Loughrey A, Earle JAP, et al. Antibacterial activity of honey against community-associated methicillin-resistant Staphylococcus aureus (CA-MRSA). Complement Ther Clin Pract 2008; 14(2): 77-82.

[138] Yusof N, Hafiza AHA, Zohdi RM, Bakar MZA. Development of honey hydrogel dressing for enhanced wound healing. Radiat Phys Chem 2007; 76(11-12): 1767-70.

[139] Alnaqdy A, Al-Jabri A, Al Mahrooqi Z, Nzeako B, Nsanze H. Inhibition effect of honey on the adherence of Salmonella to intestinal epithelial cells in vitro. Int J Food Microbiol 2005; 103(3): 347-51.

[140] Hanson A. In: Potter DS Ed. A companion to the roman empire, Blackwell Publishing Ltd: Malden 2006; $492-523$.

[141] Noyce JO, Michels HT, Keevil CW. Potential use of copper surfaces to reduce survival of epidemic meticillin-resistant Staphylococcus aureus in the healthcare environment. J Hosp Infect 2006; 63(3): 289-97.

[142] Wilks SA, Michels HT, Keevil CW. The survival of Escherichia coli $\mathrm{O} 157$ on a range of metal surfaces. Int J Food Microbiol 2005 105(3): 445-54.

[143] Kuhn PJ. Doorknobs: a source of nosocomial infection? Diagn Med 1983; 6(8): 62-63.

[144] Airey P, Verran J. Potential use of copper as a hygienic surface; problems associated with cumulative soiling and cleaning. J Hosp Infect 2007; 67(3): 271-7.

[145] Bragg PD, Rainnie DJ. The effect of silver ions on the respiratory chain of E. coli. Can J Microbiol 1974; 20(6): 883-9.

[146] Siva Kumar V, Nagaraja BM, Shashikala V, et al. Highly efficient $\mathrm{Ag} / \mathrm{C}$ catalyst prepared by electro-chemical deposition method in controlling microorganisms in water. J Mol Catal A Chem 2004; 223(1-2): 313-9.

[147] de Carvalho CCCR. Biofilms: recent developments on an old battle. Recent Patents Biotechnol 2007; 1(1): 49-57.

[148] Khan LK, Li R, Gootnick D. Peace Corps Thyroid Investigation Group. Thyroid abnormalities related to iodine excess from water purification units. Lancet 1998; 352(9139): 1519-20.

[149] Barata A, Caldeira J, Botelheiro R, Pagliara D, Malfeito-Ferreira M, Loureiro V. Survival patterns of Dekkera bruxellensis in wines and inhibitory effect of sulphur dioxide. Int J Food Microbiol 2008; 121(2): 201-7. 